\title{
A late-winter to early-spring temperature reconstruction for southeastern Norway from 1758 to 2006
}

\author{
Ø. NORDLI, ${ }^{1}$ E. LUNDSTAD, ${ }^{1}$ A.E.J. OGILVIE ${ }^{2}$ \\ ${ }^{1}$ Norwegian Meteorological Institute, PO Box 43, Blindern, NO-0313 Oslo, Norway \\ E-mail: oyvind.nordli@met.no \\ ${ }^{2}$ Institute of Arctic and Alpine Research, University of Colorado, Boulder, CO 80309-0450, USA
}

\begin{abstract}
Systematic temperature observations were not undertaken in Norway until the early 19th century, and even then only sporadically. Climate-proxy data may be used to reconstruct temperatures before this period, but until now there have not been any climate proxies available for late winter. This situation has recently changed, as a diary containing historical ice break-up data from a farm near lake Randsfjord in southeastern Norway has been discovered. These data, together with observations from lake Mjøsa in the same region, make it possible to reconstruct temperature back to 1758 . The reconstructed series, combined with instrumental series from the area near the lake, were merged into one composite time series covering the period 1758-2006. The lowest temperatures are seen during the Dalton sunspot minimum in the early 19 th century. The 20th century was $1.3^{\circ} \mathrm{C}$ warmer than the 19 th century, whereas the 19th century was $0.4^{\circ} \mathrm{C}$ warmer than the last 43 years of the 18th century. During the period 1758-1850, the mean temperature was $1.4^{\circ} \mathrm{C}$ lower than the mean value of the 20th century. The warmth observed in the $1990 \mathrm{~s}$ and at the start of the 21 st century is unprecedented during the whole series.
\end{abstract}

\section{INTRODUCTION}

In this paper, a new climate series of air temperature for Norway, covering the period 1758-2006, is presented, and made available for further analysis. The series reflects data for the late-winter to early-spring season, and is based on ice break-up data from the southeastern part of the country. The

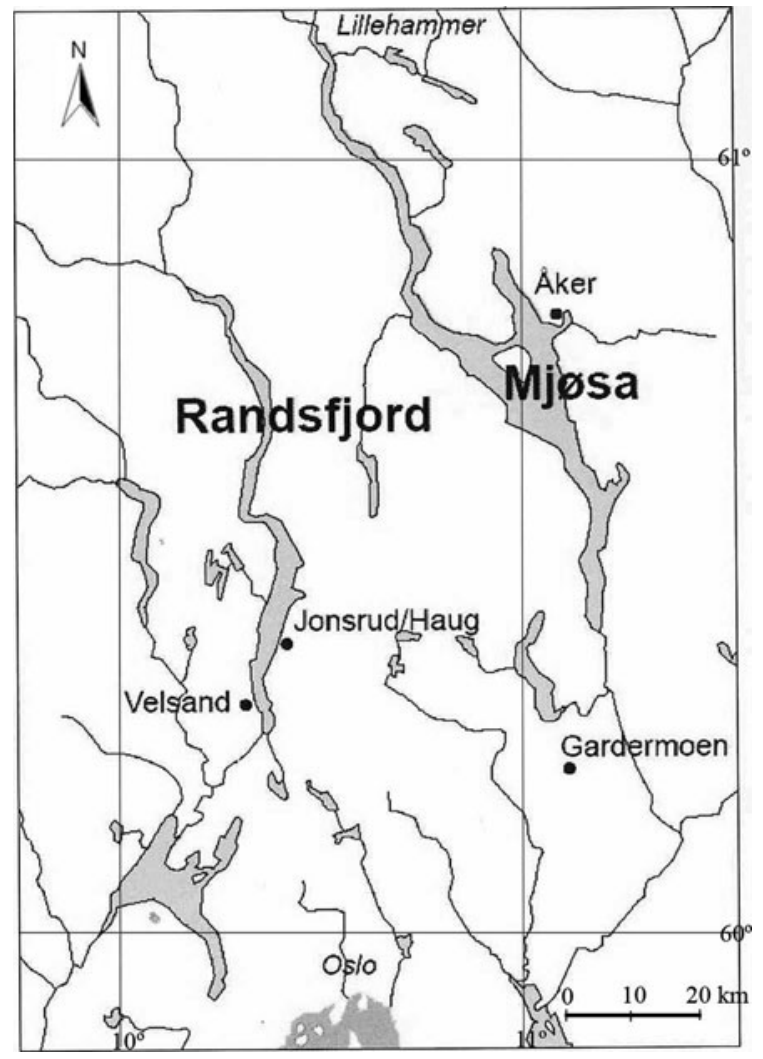

Fig. 1. The Randsfjord and Mjøsa district in southeastern Norway. series is potentially of great value for its contribution to knowledge of the climate prior to the era of systematic meteorological observations, and is of particular relevance for study of the climate of the last millennium. This has been the focus of much attention, not least because of the interest in periods during this time-span that have come to be designated as the Medieval Warm Period (MWP) and the Little Ice Age (LIA). These hypothesized climatic periods have become so well known that they have even entered the popular literature, and many scholars have debated the evidence for them (see, e.g., Lamb, 1965, 1977; Williams and Wigley, 1983; Grove, 1988; Hughes and Diaz, 1994).

Debates concerning the timing of the so-called MWP and the LIA, and indeed whether the terminology is appropriate, continue (see, e.g., Briffa, 2000; Jones and others, 2001; Ogilvie and Jónsson, 2001; Bradley and others, 2003). However, most reconstructions do show minimum values in the traditional time-span of the so-called LIA ( 1550-1850) (see, e.g., Mann and others, 1999; Moberg and others, 2005a; Osborn and Briffa, 2006). That there were periods with very cold climatic regimes in Scandinavia during the 18th and 19th centuries is evident (see, e.g., Lauritzen and Lundberg, 1999; Nordli and others, 2003). However, early instrumental observations (e.g. from Stockholm and Uppsala) suggest quite large variations in climate within and also between individual seasons (Moberg and others, 2003).

The new series described here is based primarily on accounts of lake-ice break-up recorded in farm diaries kept in the vicinity of lake Randsfjord in the county of Oppland in southeastern Norway (Fig. 1). Although the term 'fjord' is usually reserved for a salt-water inlet, it is also sometimes used in Norway to denote a lake with a narrow fjord-like shape. Lake Randsfjord is Norway's fourth largest freshwater lake and covers an area of approximately $138 \mathrm{~km}^{2}$. The background to the discovery of the ice break-up data may be outlined briefly. In the late winter of 2003, the Norwegian Meteorological Institute (NMI) received a telephone call 
from a farmer named Torstein Johnsrud, whose farm was located very near lake Randsfjord (Fig. 1). Johnsrud contacted the NMI to make it known that there was a diary at the 'Jonsrud' farm that contained ice break-up data commencing in 1769. To say that this news was sensational would be an understatement, as the diary information began almost 100 years prior to any previously known systematic lake-ice observations in Norway. Before the availability of the Randsfjord data, information on 18th-century lake-ice break-up was only sporadic, and only available for lake Mjøsa (Lundstad, 2004).

In Norway's neighbours, Finland and Sweden, systematic observations of ice break-up have been carried out on several lakes for more than 100 years (Korhonen, 2006; A. Eklund, unpublished information). The oldest observations, commencing in 1712, are from lake Mälaren, situated near the small town of Västerås, not far from Stockholm. These and other time series of ice break-up can be valuable indicators of climatic change. Shorter time series of ice break-up are also useful. Basing their conclusions on these latter types of data, Duguay and others (2006) detected trends towards earlier ice break-up for most of the Canadian lakes during the second part of the 20th century. A comparative survey of ice break-up data for 24 lakes and rivers in the Northern Hemisphere (Magnuson and others, 2000) also shows a change towards earlier break-up dates from 1846 to 1995 . For four Finnish lakes in the survey, ice break-up occurred 79 days earlier per 100 years. The ice break-up series for lake Mälaren has been used for the purpose of temperature reconstruction (Moberg and others, 2005b). This reconstruction is compared in the present paper with the results derived from lake Randsfjord.

\section{DATA}

The seven datasets used here in the reconstruction of climate indices of air temperature for southeastern Norway are described below. The principal data series of lake-ice breakup originates from the Jonsrud farm (Fig. 1). In addition, other series from lakes Randsfjord and Mjøsa are used for filling in gaps in the series from Jonsrud and for extrapolating it back to 1758 .

1. Jonsrud farm diary (1769-1879, 2003-06; 12 missing years within the periods). The farmhouses are situated about $70 \mathrm{~m}$ above lake Randsfjord with an excellent view of the lake. Some ice-break-up dates are taken from the neighbouring Haug farm diary (1978-2006, 12 missing years) which has the same view of the lake as the Jonsrud farm.

2. Ice maps of lake Randsfjord (1978-2005; 8 missing years). These maps have been constructed for each winter from 1978 onwards by the Norwegian Water Resources and Energy Directorate (NVE). The time series extracted from the maps comprise dates of ice break-up on the lake surface that is seen from the Jonsrud and Haug farms. It is possible to study how the edge of the ice cover expands northward from the southern end of the lake during freezing. During ice break-up, however, the ice seems to disappear almost simultaneously over the whole area from the outlet upstream to the Jonsrud farm. However, it is not always possible to deduce the exact dates for the ice break-up from the maps, and hence these data are missing for 8 years of the record.
3. Velsand farm diary (1945-90; 2 missing years). This farm is situated on the western shore of lake Randsfjord, i.e. on the opposite shore to the Jonsrud farm. There is also an excellent view to the fjord from this farm, as it is situated on a headland close to the lake (Fig. 1). The data include 10 years that overlap with the NVE mapping, during which time the ice broke up 0.7 days earlier at Jonsrud than at Velsand. (The correlation was 0.97 and the difference was not significant according to a $t$ test.) Both the Velsand farm and NVE observations are adopted in the Randsfjord series of break-up dates without any adjustments.

4. Åker farm diaries (1758-1834; 42 missing years). This series is based on observations made by three generations of farmers. The location is a large farm (Fig. 1) situated near an inlet of lake Mjøsa, Akersvika, to the south and east of the farm. This series commences in 1758, 11 years before the Jonsrud series, but is, unfortunately, far from complete. The dataset was brought to the attention of the scientific community by Lundstad (2004).

5. Ship observations from lake Mjøsa (1865-1900). This data series is already published (Holmsen, 1902). It is based on a diary of Captain Gustav Adolf Raabe and his son Aksel, on board steamships traversing lake Mjøsa. Raabe's break-up dates for certain areas of the lake were standardized by Holmsen.

6. Instrumental observations from Gardermoen airport (1945-2006). The Gardermoen station is situated to the north of Oslo in the continental climate zone (Fig. 1). Its series is tested and can be considered homogeneous throughout the whole period of observation.

7. Regional series (1876-2005). This series is an updated version of regionalized temperatures for southeastern Norway (Hanssen-Bauer and Nordli, 1998). During the standard normal period (1961-90) the series is adjusted to the same mean temperature and standard deviation as the Gardermoen series.

\section{CONSTRUCTING AN ICE BREAK-UP INDEX FOR LAKE RANDSFJORD}

The ice break-up index for Randsfjord (IBR) is defined as the number of days counted from 1 January to the day of the ice break-up, sometimes also called Julian days. When both the start and end dates of the ice break-up are known, the mean value of the two dates is adopted for the IBR. During unusually mild winters the ice cover does not become established on Randsfjord, and in these cases the ice index is set to zero.

Similar ice break-up indices have been established for lake Mjøsa, for the inlet to the south of the Åker farm (IBA) and for an area near Lillehammer (IBL). These indices correlate well with the IBR, and linear relationships are established by regression analyses based on 14 and 9 overlapping years, respectively.

$$
\begin{aligned}
& \mathrm{IBR}=13.07+0.914 \mathrm{IBA} \\
& \mathrm{IBR}=6.46+0.904 \mathrm{IBL}
\end{aligned}
$$

The correlation between IBR and IBA is 0.96 and between IBR and IBL it is 0.97 . In calculating the standard deviation of the $N$ residuals a technique termed 'cross-validation' or 


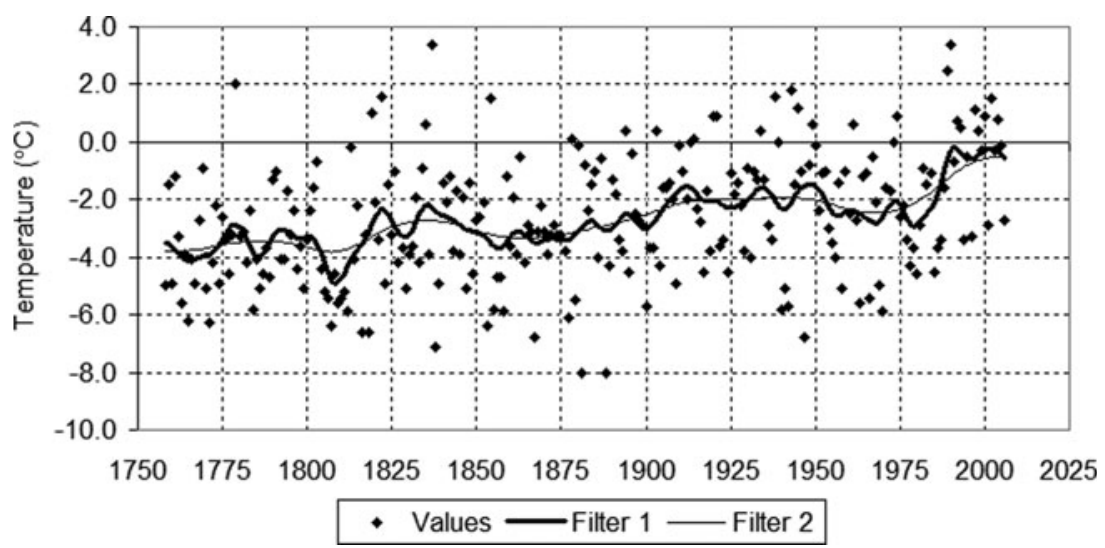

Fig. 2. Composite series of mean February-April air temperature near lake Randsfjord, reconstructed from ice break-up data (1758-1874) and using instrumental observations (1875-2006). The series are smoothed by Gaussian low-pass filters removing variations on smaller timescales than a decade (filter 1 ) and 30 years (filter 2 ).

'leave-one-out' was used (see, e.g., Wilks, 1995, p. 194). The residuals were treated case-by-case, with different regression equations using the same predictors. To define the residual for each case, that case was omitted, and the regression was based on the remaining $N-1$ cases. This procedure was in turn repeated for each residual. Thus, the case that was used for validation had no influence on the regression used for calculation of that specific residual. By this technique the standard deviations of the residuals for the IBR in Equations (1) and (2) are 3.5 days and 4.5 days, respectively.

The Aker series suffers a discrepancy in continuity with the ice break-up of 1804 . During that winter, the third generation of farmers began a continuation of the diary. The farmer in question also reported on the ice cover of the main water body, lake Mjøsa. It is not always clear which body of water he refers to, the main one or the inlet, so this part of the series has not been used after 1803 .

After the adjusted data from lake Mjøsa are added, the IBR consists of ice break-up dates for a total of 196 years: 1758-1900 and 1945-2006. In the early and late periods, 7 and 3 years are missing, respectively. For the intermediate interval 1901-44, data exist for the deep part of lake Mjøsa around its island (Fig. 1), but these are poorly correlated with break-up dates on lake Randsfjord. For that reason they are not used here.

\section{TEMPERATURE RECONSTRUCTIONS}

The development of a transfer function between IBR and meteorological variables requires a period of sufficient length for calibration. Taking into account the available meteorological stations, the data coverage of the IBR, and the start of a hydroelectric power plant at the lake, the period 1945-89 was chosen. Only winters with stable ice cover were included, for which the criterion IBR > 90 was used; i.e. the ice cover should persist at least until 1 April. Four cases of unstable or non-existent ice occurred, reducing the calibration dataset to 41 cases, i.e. 41 years within the 45 year period.

The variability of the IBR is mainly a consequence of the energy exchange between the lake surface and the lake's environment. The energy exchange in the early winter, however, may have little influence compared to that in late winter and early spring (A. Eklund, unpublished information). This suggestion was examined by multiple regression analysis, with the monthly mean temperatures as predictors and the IBR as predictand. The monthly means are intercorrelated so that there might be a risk for over-fitting the regression. The problem was reduced by including additional predictors in the regression only when significant at the 0.05 level according to an $F$ test. If it was not significant at the 0.10 level in a backward regression, the predictor was also rejected. The result was that three predictors were of significance: the mean temperatures in February, March and April. The regression correlation, $R$, was $0.75\left(R^{2}=0.56\right)$. The partial correlations between the IBR and the mean temperatures were $-0.65,-0.48$ and -0.63 for February, March and April, respectively. For May, the correlation was not significant, although $41 \%$ of the ice break-ups did occur in May.

Further analysis involved taking the mean temperature for the three significant months, $T_{\mathrm{FMA}}$, as predictand in a simple linear regression analysis with the IBR as predictor. A linear transfer function was thereby established between IBR and February-April (FMA) mean temperature:

$$
T_{\mathrm{FMA}}=17.60-0.168 \mathrm{IBR} \text {. }
$$

The regression correlation, $R$, was $0.76\left(R^{2}=0.58\right)$, and, based on cross-validation (leave-one-out) technique, the standard deviation of the residuals is $1.3^{\circ} \mathrm{C}$. By using the regression equation, $T_{\mathrm{FMA}}$ was reconstructed for all years where IBR $>90$. For IBR $\leq 90$ or IBR missing, one of the nearest available meteorological stations was used for interpolations of individual years (the period 1901-44 is missing). For the adjustment, only the neighbouring 10 years on either side of the missing year were considered. By these means, the influence of the interpolated values (taken from potentially inhomogeneous meteorological series) on longterm trends of the reconstructed series was avoided.

In constructing a composite temperature series (Fig. 2) the reconstructed series is used for the period 1758-1875. For the period 1945-2006, data are taken from the Gardermoen series (Fig. 1) that starts in 1945; and, in the intermediate period 1876-1944, the data are from a regional series (see section 2). Thus, a complete series covering the period 1758-2006 is made available for further analyses.

First, the series is analyzed for linear trend. A significant $(p<0.01)$ trend of $0.100^{\circ} \mathrm{C}$ per decade was detected, which for the whole period of 249 years amounts to $2.5^{\circ} \mathrm{C}$ for the FMA temperature. However, temperature has undergone large variations on different timescales through the centuries. 
These are more closely studied when two Gaussian low-pass filters are used to smooth out variations on timescales shorter than 10 and 30 years. Concerning the decadal variations, the coldest period is centred around 1809 . It is about $0.8^{\circ} \mathrm{C}$ colder than the second coldest, which is the one centred around 1766 . Over the past 50 years, the diagram also shows a period of low temperatures around 1980. The warm temperatures of the 1990s through to the present can clearly be seen on the graph. This discussion of the climatic regimes of different periods is continued in section 6 .

\section{DISCUSSION}

The transfer function from IBR to FMA temperature was based on the late period from 1945 to 1989, not to 2006 as might be expected. The reason for this is that a water reservoir for electric power production was established in the winter of 1989/90 which had the effect of increasing water flow through the lake. Although this may have had very little influence on the IBR (Wold, 1980), the regulated period was left out of the calibration dataset. The influence of the regulation was tested by reconstructing the FMA temperature (Equation (3)) for the years 1990-2006. The mean temperature for the period obtained by reconstruction was $0.07^{\circ} \mathrm{C}$ lower than observed, i.e. no significant effect of the regulation is detected.

The stationarity of the regression equation was tested by using the last 21 years as a training period (1967-89), while using the remaining 20 years (1945-66) as a validation period. The mean difference between observed and reconstructed temperature was only $-0.1{ }^{\circ} \mathrm{C}$ in the validation period, indicating that the regression equation is stationary.

A more difficult concern regarding the homogeneity of the IBR for the whole series is due to the lack of a precise definition of the IBR. In some years, the ice remains at the same general location while melting, whereas in other years the ice cover is subject to abrupt dispersion by wind. The opinion of the present farmer at Jonsrud is that if a hole is established in the ice, it will seldom last more than 2-3 days before the total break-up occurs. For most years, the Jonsrud diary only gives one break-up date, but for some years the beginning as well as the ending of the ice break-up is given. If more than one date is given, the mean value is used for the IBR. However, even in the latter years, the difference between the end and the start date is usually not more than 1 day, and in no case is it more than 4 days. From Equation (3) it may be seen that, for example, a difference of 2 days in the IBR results in a difference of about $0.3^{\circ} \mathrm{C}$ in the reconstruction.

For IBR $>90$ during the unregulated period of the lake, 1945-89, the standard deviation of the residuals amounted to $1.3^{\circ} \mathrm{C}$. However, if the observations are assumed to be uncorrelated from year to year (no significant autocorrelation is detected), the standard error for the mean value of a decade reduces to $0.4{ }^{\circ} \mathrm{C}$, and the $95 \%$ confidence interval is roughly $0.8^{\circ} \mathrm{C}$ for a decadal mean value. For a century the standard deviation of the mean value reduces further to about $0.1^{\circ} \mathrm{C}$. The relatively low regression correlation therefore has no major impact on mean temperature for a whole century nor for the multi-centurial trends.

The variability of the FMA temperature seems to be greater in the instrumental period than in the proxy-data period, but this may be an artefact caused by the method itself as the regression method suppresses variability. How large the suppression is in this case may be studied during
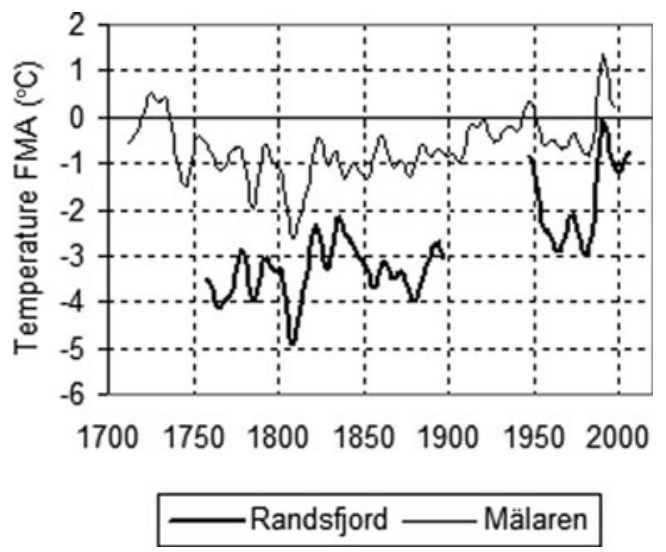

Fig. 3. Mean February-April air temperature reconstructed by ice break-up data for the two lakes Randsfjord, southeastern Norway, $\left(60.4^{\circ} \mathrm{N}, 10.6^{\circ} \mathrm{E}\right)$ and Mälaren, eastern Sweden (near Stockholm; $59.6^{\circ} \mathrm{N}, 16.5^{\circ} \mathrm{E}$ ). Both series are smoothed by Gaussian low-pass filters removing variations on smaller timescales than decades. (The coordinates refer to the parts of the lakes where the ice break-up is observed.)

the period where both instrumental and reconstructed temperatures exist. The ratio between the standard deviation of the observed temperatures and the standard deviation of the estimates for the period 1945-89 is 1.3. A factor of about 1.3 is also expected to occur for time intervals outside the calibration period. The composite series should therefore not be used for variability studies.

A reconstructed temperature series based on ice breakups is also available for lake Mälaren (see section 1). As for lake Randsfjord, its ice break-up index is correlated with the mean February-April temperature, $R=0.78\left(R^{2}=0.61\right)$. The time evolutions of the two reconstructions (Fig. 3) show mainly the same pattern, with maxima and minima located nearly in the same years.

However, the temperature seems to have been relatively lower at Randsfjord than at Mälaren during the reconstructed part of the LIA compared to the present climate. Thus, the difference between the reconstructions for Mälaren and Randsfjord is $1.72^{\circ} \mathrm{C}$ during the present climate (1945-99), whereas the corresponding difference is $2.18^{\circ} \mathrm{C}$ for the LIA climate during the period 1758-1850, leaving Randsfjord relatively colder during this time by $0.46^{\circ} \mathrm{C}$. It is possible that the difference may be partly an artefact if the opinions among the observers have changed through the long period of observation. The question is, how much ice should melt before the observers register the situation as an ice break-up?

The relative coldness of the Randsfjord series during the period 1758-1850 might also be seen in the context of climate change from the LIA climate to the present climate. Comparison of the Stockholm and Gardermoen instrumental recorded FMA temperatures during the period 1945-2004 reveals significantly $(p<0.05)$ larger differences between the series for high IBR (cold cases) than for low IBR (mild cases). It is plausible that this holds also for the LIA. The physical interpretation is that the inland areas may cool more in high-pressure situations than the coastal areas. The Randsfjord area is situated farther from large ice-free open-water bodies than the areas around Mälaren. A more continental climate during the LIA may have had a greater influnce on the inland districts than the coastal districts and thus be responsible for the cold LIA anomaly for the Randsfjord area. 
Although the Randsfjord series supports the view of a generally cold climate during the period 1758-1850, it is also clear that there were fluctuations in temperature during the so-called LIA. Thus, the Mälaren series shows that the FMA climate in the first part of the 18th century was mild (Fig. 3). This is also supported by a reconstruction based on the first ship entering the Tallinn harbour in Estonia (Tarand and Nordli, 2001).

\section{CONCLUSIONS}

The lake ice break-up data presented here have the potential to amplify and illuminate knowledge of climate variations in southeastern Norway during the period from the mid-18th century to the present. The length of the record enables the calculation of long-term trends, and the dataset is also potentially of value in establishing natural climate variability prior to the anthropogenic era. It is important to note, however, that the reconstruction may be biased up to $0.3^{\circ} \mathrm{C}$ if the perception of what exactly is meant by the date of ice break-up has changed in the time-span from the early observers in the 18th and 19th centuries to the observers in the 20th century. The trends in the series may be described as follows: The 20 th century was $1.3^{\circ} \mathrm{C}$ warmer than the 19 th century, whereas the 19 th century was $0.4^{\circ} \mathrm{C}$ warmer than the last 43 years of the 18th century. The lowest temperatures of the series are seen during the Dalton sunspot minimum in the early 19th century. The first half of the 20th century was also relatively mild, with local maxima in 1913, 1935 and 1949. Other warm periods are seen in the first part of the 19th century concentrated around 1823 and 1836. Thus, as the lowest temperatures of the whole series are located near those maxima, the first half of the 19th century exhibits large decadal variability like the last part of the series. Further notable features are that during the period 1758-1850 the FMA mean temperature was $1.4^{\circ} \mathrm{C}$ lower than during the 20th century. The well-known period of mild late wintersearly springs in the 1990s and at the start of the 21 st century is unprecedented during the 249 years of the series.

\section{ACKNOWLEDGEMENTS}

First of all, we wish to thank T. Johnsrud for providing us with the principal ice break-up series, and $\varnothing$. Nordli acknowledges the Norwegian Research Council for funding this work through the Norpast-2 project. These two events have made this temperature reconstruction possible. We are also in debt to the late Erik Velsand for having extracted the data from the Velsand diary, and to the Haug family for kindly providing us with the Haug diaries, as well as to NVE for having opened the map archive for us. A. Ogilvie acknowledges inspiration from the European Science Foundation (ESF) Boreal Ecosystem-Atmosphere Study (BOREAS) and support from US National Science Foundation grant 0638897. We also express our gratitude to our reviewer M.P. Lacroix for many helpful comments.

\section{REFERENCES}

Bradley, R.S., K.R. Briffa, J. Cole, M.K. Hughes and T.J. Osborn. 2003. The climate of the last millennium. In Alverson, K.D., R.S. Bradley and T.F. Pedersen, eds. Paleoclimate, global change and the future. Berlin, etc., Springer Verlag.
Briffa, K. 2000. Annual climate variability in the Holocene: interpreting the message of ancient trees. Quat. Sci. Rev., 19(1-5), 87-105.

Duguay, C.R., T.D. Prowse, B.R. Bonsal, R.D. Brown, M.P. Lacroix and P. Ménard. 2006. Recent trends in Canadian lake ice cover. Hydrol. Process., 20(4), 781-801.

Grove, J.M. 1988. The Little Ice Age. London, Methuen \& Co. Ltd.

Hanssen-Bauer, I. and Nordli, P.Ø. 1998. Annual and seasonal temperature variations in Norway 1876-1997. Oslo, Det Norske Meteorologiske Institutt. (DNMI KLIMA Rapp. 25/98.)

Holmsen, A. 1902. Isforholdene ved de norske indsjøer. Videnskapsselskapets Skr. 4, 17-38.

Hughes, M.K. and H.F. Diaz. 1994. Was there a 'Medieval Warm

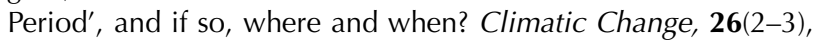
109-142.

Jones, P.D., A.E.J. Ogilvie, T.D. Davies and K.R. Briffa. 2001. Unlocking the doors to the past: recent developments in climate and climate-impact research. In Jones, P.D., A.E.J. Ogilvie, T.D. Davies and K.R. Briffa, eds. History and climate: memories of the future? Dordrecht, etc., Kluwer Academic/Plenum Publishers, 1-8.

Korhonen, J. 2006. Long-term changes in lake ice cover in Finland. Nord. Hydrol., 37(4-5), 347-363.

Lamb, H.H. 1965. The early medieval warm epoch and its sequel. Palaeogeogr., Palaeoclimatol., Palaeoecol., 1(1), 13-37.

Lamb, H.H. 1977. Climate: present, past and future. 2: Climatic history and the future. London, Methuen.

Lauritzen, S.-E. and J. Lundberg. 1999. Calibration of the speleothem delta function: an absolute temperature record for the Holocene in northern Norway. Holocene, 9(6), 659-669.

Lundstad, E. 2004. Rekonstruksjon av klimaet på Hamar 1749-1835 basert på gårdsdagbøker. (Master's thesis, University of Bergen.)

Magnuson, J.J. and 13 others. 2000. Historical trends in lake and river ice cover in the Northern Hemisphere. Science, 289(5485), 1743-1746.

Mann, M.E., R.S. Bradley and M.K. Hughes. 1999. Northern Hemisphere temperatures during the past millennium: inferences, uncertainties and limitations. Geophys. Res. Lett., 26(6), 759-762.

Moberg, A., H. Alexandersson, H. Bergström and P.D. Jones. 2003. Were southern Swedish summer temperatures before 1860 as warm as measured? Int. J. Climatol., 23(12), 1495-1521.

Moberg, A., D.M. Sonechkin, K. Holmgren, N.M. Datsenko and W. Karlén. 2005a. Highly variable Northern Hemisphere temperatures reconstructed from low- and high-resolution proxy data. Nature, 433(7026), 613-617.

Moberg, A., H. Tuomenvirta and Ø. Nordli. 2005b. Recent climatic trends. In Seppälä, M., ed. The physical geography of Fennoscandia. Oxford, etc., Oxford University Press, 113-133.

Nordli, P.Ø., Ø. Lie, A. Nesje and S.O. Dahl. 2003. Springsummer temperature reconstruction in western Norway 17342003: a data-synthesis approach. Int. J. Climatol., 23(15), 1821-1841.

Ogilvie, A.E.J. and T. Jónsson. 2001. 'Little Ice Age' research: a perspective from Iceland. Climatic Change, 48(1), 9-52.

Osborn, T.J. and K.R. Briffa. 2006. The spatial extent of 20thcentury warmth in the context of the past 1200 years. Science, 311(5762), 841-844.

Tarand, A. and P.Ø. Nordli. 2001. The Tallinn temperature series reconstructed back half a millennium by use of proxy data. Climatic Change, 48(1), 189-199.

Wilks, D.S. 1995. Statistical methods in the atmospheric sciences. San Diego, CA, Academic Press.

Williams, L.D. and T.M.L. Wigley. 1983. A comparison of evidence for Late Holocene summer temperature variations in the Northern Hemisphere. Quat. Res., 20(3), 286-307.

Wold, K. 1980. Vanntemperatur og isforhold i Etna/Dokkavassdraget og Randsfjord. NVE Rep. 2-80. 